\title{
Predgovor
}

\section{Sonja Rutar}

Univerza na Primorskem

sonja.rutar@pef.upr.si

\section{Darjo Felda}

Univerza na Primorskem

darjo.felda@pef.upr.si

\section{Martina Rodela}

Univerza na Primorskem

martina.rodela@pef.upr.si

\section{Nina Krmac}

Univerza na Primorskem

nina.krmac@pef.upr.si

\section{Mateja Marovič}

Univerza na Primorskem

mateja.marovic@pef.upr.si

\section{Karmen Drljić}

Univerza na Primorskem

karmen.drljic@pef.upr.si

V monografiji, v kateri sodelujejo kolegi z različnih znanstvenih področij in iz različnih disciplin, obravnavamo prehode $v$ socialnih ter izobraževalnih okoljih. Monografija je v slovenskem prostoru prvo delo, osredotočeno na vsebinsko različne prehode, ki pogosto niso prepoznani in deležni posebne pozornosti. Obravnava situacije, za katere je značilen prehod iz znanega v neznano okolje oz. prehajanje v nove okoliščine, ki so v nekem trenutku za posameznika lahko tudi življenjskega pomena.

Razprave in prispevki nakazujejo, da so prehodi dinamični in večplastni procesi, ki vključujejo do sedaj pogosto spregledane dejavnike - doživljanje pozameznikov, odnose in pogoje $v$ okolju. Ker prehodi niso pogosto obravnavani in ne izpostavljeni kot pomemben element uspešnega vključevanja v nova okolja, je lahko posameznik ob svojem subjektivnem doživljanju le-teh pogosto sam oz. celo osamljen.

Razmere, ki so nastale kot posledica epidemije covida-19, so bile sprožilec, ki nas je spodbudil k razmišljanju o pomenu, doživljanjih in posledicah hitrih 
prilagajanj na nove okoliščine, ki vodijo v negotovost, obenem pa predstavljajo priložnosti za učenje, razvoj in odločanje. Čeprav zahtevne in nepredvidljive, pa lahko tovrstne situacije prispevajo k razvijanju zmožnosti posameznika za proaktivno sooblikovanje in preoblikovanje okoliščin ter situacij.

$V$ domačem in mednarodnem okolju sta bila do sedaj najpogosteje obravnavana odnos in prehod med vrtci ter šolo (Moss 2013; OECD 2017; Vidmar idr. 2017). Kot pogoj za učno uspešnost $v$ osnovnih šolah se je pogosto poudarjala pripravljenost, zrelost otroka za vstop v šolo. Pripravljenost za prehod v novo okolje je bila razumljena kot univerzalno stanje, ki ga je mogoče tehnično realizirati. Pri tem pa ni bila zadostno poudarjena interakcija med različnimi okolji.

Ob dejstvu, da prehodi lahko predstavljajo kritično in občutljivo obdobje v posameznikovem življenju, nas zanima, kaj se s posameznikom dogaja v času prehodov iz domačega okolja v vrtec, iz osnovnošolskega v srednješolsko izobraževanje in iz srednješolskega izobraževanja v visokošolsko. $V$ monografiji so obravnavani tudi prehodi, ki se dogajajo ob vstopanju v različna socialna in delovna okolja ter skozi celotno življenjsko obdobje - na vertikalni in horizontalni ravni, v mikro- in makrookoljih ter sistemih. V monografiji so tako natančneje analizirani in obravnavani prehodi v predšolskem in osnovnošolskem obdobju, predmetnospecifični prehodi z vidika didaktične diferenciacije in individualizacije, prehodi pri specifičnih vzgojno-izobraževalnih potrebah posameznikov, prehodi v visokošolsko izobraževanje in $v$ delovna okolja ter karierni razvoj posameznikov s profesionalnimi prehodi.

Nagovoriti želimo raziskovalce, učitelje, starše, dijake, študente, strokovne delavce, ki doživljajo različne prehode in so pogosto vključeni tudi v njihovo organizacijo in izvedbo. Predvidevamo, da bodo razprave in prispevki pripomogli predvsem k boljšemu uvidu v do sedaj v manjši meri obravnavana področja, njihov interdisciplinaren pristop pa k učenju in spoznavanju priložnosti in načel, ki bi jih bilo mogoče prilagojeno prevzeti v drugih okoljih.

Zahvaljujemo se vsem, ki so sodelovali pri nastajanju te monografije in tako pomembno prispevali $k$ preučevanju mnogoterih vidikov raznolikih prehodov. $\mathrm{S}$ tem ste prispevali k razumevanju doživljanj ter vpetosti posameznikov in skupin $v$ različne sisteme ter okolja.

\section{Literatura}

Moss, P., ur. 2013. Early Childhood and Compulsory Education: Reconceptualising the Relationship. Routledge: New York.

OECD. 2017. Starting Strong V: Transitions from Early Childhood Education and Care to Primary Education. Pariz: OECD. 
Vidmar, M., T. Rutar Leban in S. Rutar. 2017. Transitions from Early Childhood Education and Care to Primary Education: OECD Review of Policies and Practices for Transitions from ECEC to Primary Education; Country Background Report Slovenia. Ljubljana: Ministry of Education, Science and Sport in National Educational Institute Slovenia. 